\title{
Methanol exchange between grassland and the atmosphere
}

\author{
A. Brunner, C. Ammann, A. Neftel, and C. Spirig \\ Agroscope Reckenholz-Tänikon Research Station ART, Reckenholzstrasse 191, 8037 Zürich, Switzerland
}

Received: 8 January 2007 - Published in Biogeosciences Discuss.: 26 January 2007

Revised: 25 April 2007 - Accepted: 9 June 2007 - Published: 26 June 2007

\begin{abstract}
Concentrations and fluxes of methanol were measured above two differently managed grassland fields (intensive and extensive) in central Switzerland during summer 2004. The measurements were performed with a proton-transfer-reaction mass-spectrometer and fluxes were determined by the eddy covariance method. The observed methanol emission showed a distinct diurnal cycle and was strongly correlated with global radiation and water vapour flux. Mean and maximum daily emissions were found to depend on grassland species composition and, for the intensive field, also on the growing state. The extensive field with a more complex species composition had higher emissions than the graminoid-dominated intensive field, both on an area and on a biomass basis. A simple parameterisation depending on the water vapour flux and the leaf area index allowed a satisfying simulation of the temporal variation of methanol emissions over the growing phase. Accumulated carbon losses due to methanol emissions accounted for 0.024 and $0.048 \%$ of net primary productivity for the intensive and extensive field, respectively. The integral methanol emissions over the growing periods were more than one order of magnitude higher than the emissions related to cut and drying events.
\end{abstract}

\section{Introduction}

Methanol is one of the most abundant oxygenated volatile organic compounds in the atmosphere with typical surface concentrations of 1-10 ppbv over land and marine concentrations of 0.5-1.5 ppbv (Jacob et al., 2005; Singh et al., 2000). Its role in atmospheric chemistry is significant as it influences the concentrations of various oxidants. Formaldehyde, ozone and peroxy radical concentrations are enhanced while

Correspondence to: A. Neftel

(albrecht.neftel@art.admin.ch)
$\mathrm{OH}$ radical levels are decreased through the atmospheric reactions of methanol. The effects are most pronounced in the free troposphere, where concentrations of other reactive organic compounds are small while methanol still prevails due to its comparably long atmospheric lifetime of 8-12 days (Tie et al., 2003).

$11-20 \%$ of the methanol in the atmosphere are of anthropogenic and atmospheric origin, while the major part $(80-89 \%)$ is of biogenic origin (Heikes et al., 2002; Galbally and Kirstine, 2002; Jacob et al., 2005). Processes leading to biogenic methanol emission are manifold. Several authors reported methanol emission as part of the plant metabolism particularly during growth (e.g. Schulting et al., 1980; Isidorov et al., 1985; MacDonald et al., 1993; Fall and Benson, 1996; Karl et al., 2002). Plant stresses like hypoxia, frost and high ozone concentrations can also cause methanol emissions (Fukui and Doskey, 1998; von Dahl et al., 2006). In addition, senescing, injuring (e.g. herbivore attacks, cutting) and drying of plant leaves as well as biomass burning are known to be sources of methanol (de Gouw et al., 1999; Warneke et al., 2002; Karl et al., 2005; Loreto et al., 2006; Holzinger et al., 1999 and 2004). The major removal processes for methanol are oxidation by $\mathrm{OH}$ radicals (in the gas and the aqueous phase; Monod et al., 2000) as well as dry and wet deposition (Heikes et al., 2002; Galbally and Kirstine, 2002; Jacob et al., 2005).

Concerning the metabolism related methanol release, Frenkel et al. (1998) found that methanol within the leaf is mostly produced as a consequence of the demethylation of the pectin matrix, a necessary step in the extension of the cell walls during plant growth. On the basis of the pectin content, Galbally and Kirstine (2002) distinguished between two major cell wall types with a high or low potential for methanol release. In particular graminoids of the family poaceae, to which the main forage crops belong, are low methanol emitters. Most other plants have cell walls with a higher potential of methanol release. To a minor extent, methanol can be the

Published by Copernicus Publications on behalf of the European Geosciences Union. 


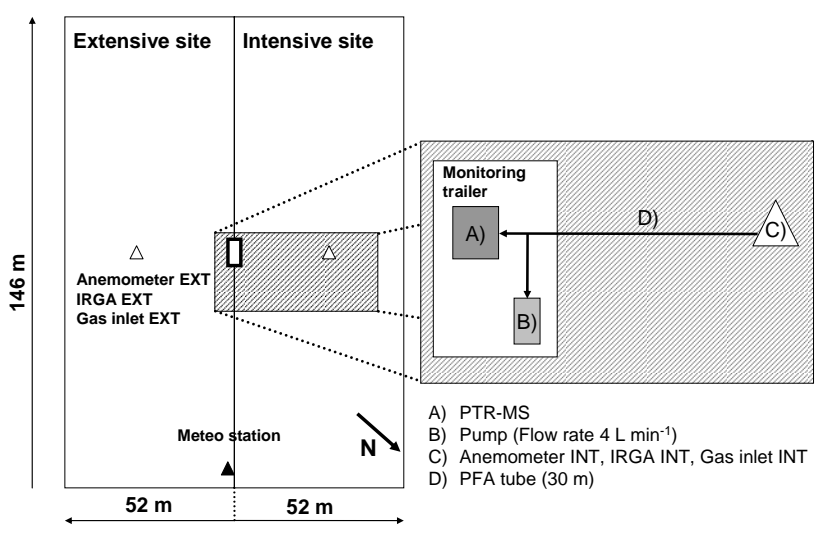

Fig. 1. Site sketch: Left: Position of the monitor trailer, the meteo station, the two anemometers, the two open-path infra-red gas analyzer (IRGA) and the gas inlets above the two fields. Right: Measurement arrangement: Gas inlet, pump, and PTR-MS.

result of an enzymatic cleavage of lignin (see Fall and Benson, 1996, and references therein), demethylation of DNA (see Galbally and Kirstine, 2002, and references therein) and protein repair pathways (Fall and Benson, 1996).

Nemecek-Marshall et al. (1995) described a distinct dependence of methanol emission on stomatal conductance. Niinemets and Reichstein (2003a, b) and Niinemets et al. (2004) relate this behaviour to a temporary storage of methanol in the liquid pools of the leaves due to its high solubility. As a consequence of this buffering effect, the production and release of methanol are not directly coupled. Because the understanding of the mechanisms controlling the methanol emission is still limited, reliable long-term emission datasets with a high temporal resolution are desirable for a variety of different ecosystems.

Until now, field measurements of biogenic methanol emissions have mainly been performed over different types of forest (e.g. Fehsenfeld et al., 1992; Schade and Goldstein, 2001; Spirig et al., 2005; Karl et al., 2005; Schade and Goldstein, 2006). Grasslands cover one quarter of the earth's land surface (Graedel and Crutzen, 1993). Apart from studies concerning the methanol emissions due to harvesting (De Gouw et al., 1999; Karl et al., 2001; Warneke et al., 2002) only few long-term flux studies exist for grassland (Kirstine et al., 1998; Fukui and Doskey, 1998). These are based on chamber measurements characterised by a low time resolution.

In this work we present methanol concentration and flux measurements above two managed grassland fields during summer 2004. The fields are located on the Swiss central plateau and differ in management intensity and species composition. Methanol was detected continuously with high temporal resolution by proton-transfer-reaction massspectrometry and the fluxes were determined by the eddy covariance technique at the ecosystem scale. We focus on the temporal variation of fluxes observed throughout a growing phase and attempt to parameterise it in a simple way based on available environmental parameters.

\section{Materials and methods}

\subsection{Site and measurement description}

The experimental site is located near Oensingen on the Swiss Central Plateau $\left(47^{\circ} 17^{\prime} \mathrm{N}, 7^{\circ} 44^{\prime} \mathrm{E} ; 450 \mathrm{~m}\right.$ a.s.l.). The prevailing climate is temperate continental, with an average annual rainfall of $1100 \mathrm{~mm}$ and a mean annual air temperature of $9^{\circ} \mathrm{C}$. The experimental field was converted from arable rotation to permanent grassland in 2001 and is part of the projects on carbon and greenhouse gas budgets CarboEurope and Greengrass (for details see Ammann et al., 2006; Flechard et al., 2005). Since 2006, this grassland is a part of the NitroEurope project. It has a size of $104 \mathrm{~m} \times 146 \mathrm{~m}$ and had been split into two parts which differ in management and species composition: (a) an intensively managed part (in the following referred to as intensive or INT) and (b) an extensively managed part (extensive or EXT). The intensive part is cut four times a year and is fertilised after each cut, alternately with slurry and ammonium nitrate. It is mainly composed of three species: two graminoids (Alopecurus pratensis, Lolium perenne), and one legume (Trifolium repens). The extensive part is cut three times a year and is not treated with any fertilizer. It is largely composed of twelve species: six graminoids (Alopecurus pratensis, Arrhenatherum elatius, Dactylis glomerata, Lolium perenne, Poa pratensis, and Poa trivialis), four forbs (Chrysanthemum leucanthemum, Stellaria media, Taraxacum officinale, and Tragopogon orientalis), and two legumes (Lotus corniculatus, and Trifolium repens).

Standard monitoring at the site included a weather station continuously measuring global radiation $\left(R_{g}\right)$, air temperature $\left(T_{\text {air }}\right)$, relative humidity $(\mathrm{RH})$, barometric pressure, rainfall, wind speed and wind direction. The prevailing wind directions are mostly along the field axis (vertical axis in Fig. 1). The single-sided leaf area index (LAI) of both fields was determined every $2-3$ weeks by an optical method (LAI2000, LI-COR, Lincoln NE, USA). Fluxes of $\mathrm{CO}_{2}\left(F_{\mathrm{CO}_{2}}\right)$ and water vapour $\left(F_{\mathrm{H}_{2} \mathrm{O}}\right)$ were routinely measured on both fields during the whole summer by eddy covariance using a combination of a sonic anemometer (Gill, Solent, Lymington, UK) and an open-path infra-red gas analyzer (IRGA, LI7500, LI-COR, Lincoln NE, USA). Figure 1 shows a sketch of the fields and the technical facilities. The $\mathrm{CO}_{2}$ assimilation rates of each field were calculated from the respective $\mathrm{CO}_{2}$ fluxes by a specific gap filling and partitioning algorithm (Ammann et al., 2007).

Methanol concentration $\left(c_{\mathrm{MeOH}}\right)$ and flux $\left(F_{\mathrm{MeOH}}\right)$ measurements above the intensive field were conducted from 25 June until 1 August 2004, between the second and the third cut of the year. Above the extensive field, methanol 
(a)

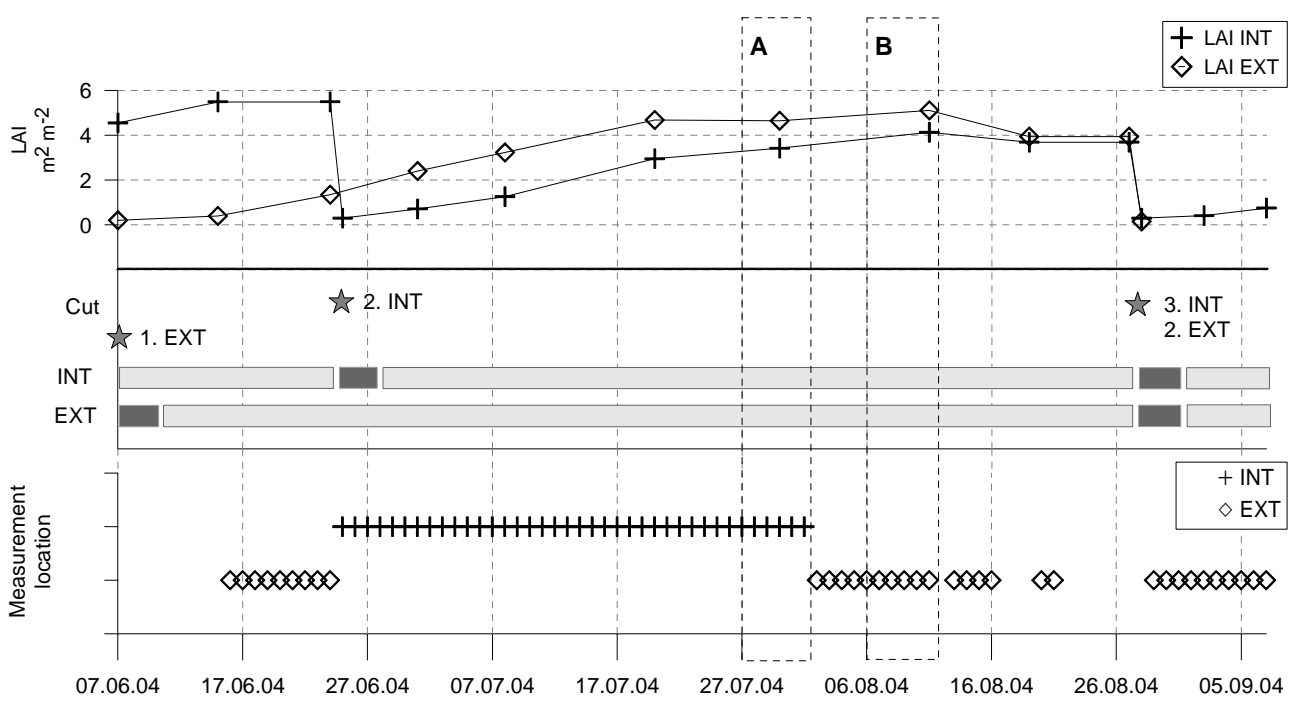

Fig. 2. Field experiment summer 2004, overview on the growing state of the fields, the event-related methanol emission, and the measurements between 7 June and 7 Sep: (a) LAI of the intensive and the extensive site, (b) cuts of the intensive (25.06 and 28.08.04) and the extensive (07.06 and 28.08.04) site, classification into cut-related (dark-grey bar) and growth-related (light-grey bar) emission periods, and (c) methanol flux sampling scheme. A: mature phase of the intensive site, B: mature phase of the extensive site.

measurements were performed from 7 until 24 June 2004 and from 2 August until 7 September 2004, covering periods between the first and the second cut of the year (Fig. 2). In the following, methanol fluxes of the first three days after a cut are referred to as cut-related emissions, the fluxes afterwards until the next cut as growth-related emissions. The corresponding periods are called cut and growing period, respectively (Fig. 2).

\subsection{PTR-MS measurements}

Methanol was measured by a commercially available protontransfer-reaction mass spectrometer (PTR-MS, Ionicon Analytik GmbH, Innsbruck, A). The instrument and its operating mode had been described in detail by Lindinger et al. (1998). Here we describe the experimental setup from the gas inlet to the instrument and go then into specifics of the PTR-MS used in this field study.

Ambient air, collected $1.2 \mathrm{~m}$ above ground, was pulled through a $30 \mathrm{~m}$ PFA-tube $\left(1 / 4^{\prime \prime}\right.$ O.D., I.D. $\left.3.5 \mathrm{~mm}\right)$ by a vacuum pump with a flow rate of $4 \mathrm{~L} \mathrm{~min}^{-1}$. The residence time in the tube was about $4.3 \mathrm{~s}$. The tube was connected to the PTR-MS inlet (Fig. 1), where the sampled air was introduced directly into a drift tube. There the reaction between $\mathrm{H}_{3} \mathrm{O}^{+}$ions (generated by electrical discharge of pure water vapour) and methanol molecules produced methanol- $\mathrm{H}^{+}$ ions (mass 33) and water molecules. The methanol- $\mathrm{H}^{+}$ions were then detected by a quadrupole mass filter in conjunction with a secondary electron multiplier (SEM, MC-217, Mascom GmbH, Bremen, D).
The PTR-MS used in this field study corresponds to the PTR-MS-HS type, featuring three turbo pumps for increased sensitivity and a drift tube (equipped with Teflon rings) optimized for fast time response and minimal interactions with polar compounds (Spirig et al., 2005). It was running under the following conditions: pressure drift tube of $2.1 \mathrm{mbar}$ and drift tube voltage of $550 \mathrm{~V}$, resulting in an electrical field strength to gas density ratio $(\mathrm{E} / \mathrm{N})$ of $122 \mathrm{Td}$. Five to eight masses were analysed in rotation: $\mathrm{m} 21$ (mass of the protonated ion with 21 atomic mass units (amu) which corresponds to a protonated water molecule with an $\mathrm{O}^{18}$-isotope), m33 (methanol), $\mathrm{m} 37$ (water cluster: $\mathrm{H}_{2} \mathrm{O} \cdot \mathrm{H}_{3} \mathrm{O}^{+}$), m45 (acetaldehyde), m59 (acetone and propanal), m73 (methyl ethyl ketone and butanal), m81 (fragments of hexenals and monoterpenes), and $\mathrm{m} 83$ (fragments of C6-alcohols). The integration time for a single compound was 50 (for $\mathrm{m} 21$ and $\mathrm{m} 37$ ) to $200 \mathrm{~ms}$ (for all other compounds), resulting in a measurement of each compound every 0.7 to $1.3 \mathrm{~s}$ (Ammann et al., 2006).

The PTR-MS was calibrated with a gas standard (ApelRiemer Environmental, Inc., Denver CO, US), that included methanol. It was dynamically diluted with air generated by a zero air generator (ChromGas Zero Air Generator, model 1000, Parker Hannifin Co., Haverhill MA, US). The absolute accuracy of the methanol concentration measurement is estimated to be $\pm 20 \%$ due to mass flow controller and gas standard uncertainties. 


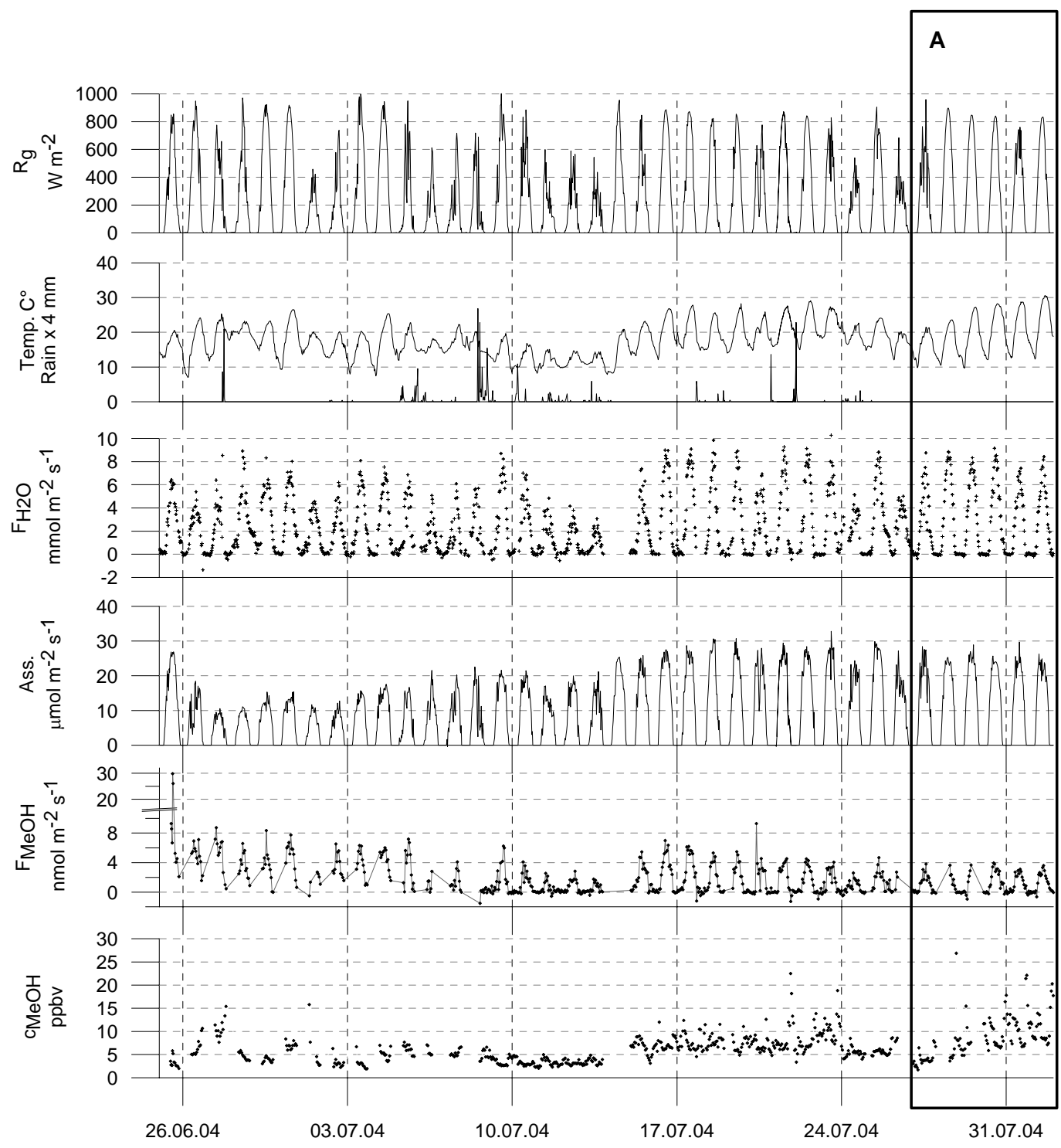

Fig. 3. Time series measured above the intensive grassland (25.06-01.08.2004), from the top to the bottom: Global radiation* $\left(R_{g}\right)$, air temperature* (Temp.), rainfall*, water vapour flux $\left(F_{\mathrm{H}_{2} \mathrm{O}}\right)$, assimilation (Ass.), methanol flux $\left(F_{\mathrm{MeOH}}\right)$, and methanol concentration $\left(c_{\mathrm{MeOH}}\right)$. (A: mature phase of the intensive site). ${ }^{*}$ measured at the meteo station, see Fig. 1.

\subsection{Eddy covariance method}

The EC flux measurement with the PTR-MS was done with the same sonic anemometers as used for the routine $\mathrm{CO}_{2}$ and $\mathrm{H}_{2} \mathrm{O}$ flux measurements (see above) placed in the middle of the grassland fields. The inlet for the PTR-MS sample air was placed close to the sonic sensor head (distance $15 \mathrm{~cm}$ ). To calculate the fluxes we used the EC calculation method described by Spirig et al. (2005). The PTR-MS measurement of the methanol ion (for $0.2 \mathrm{~s}$ ) is regarded to be representative for the whole interval of the measuring cycle (0.7$1.3 \mathrm{~s})$. Technically, this is implemented by simply repeating the PTR-MS mass concentrations of a particular cycle until the next PTR-MS data point is available. After this procedure, similar equidistant time series (time resolution $\Delta t=0.05 \mathrm{~s}$ ) of sonic wind data and methanol concentration are available for the flux calculations. Following the eddy covariance method the vertical flux of a trace gas $F_{c}$ (or of another scalar quantity) is calculated as the covariance of the discrete time series of the vertical wind $w(t)$ and the concentration $c(t)$ over an averaging period $T_{a}$ of typically $30 \mathrm{~min}$.:

$$
F_{c}=\operatorname{cov}_{w c}\left(\tau_{\mathrm{del}}\right)=\left(\frac{\Delta t}{T_{a}}\right) \times \sum_{t=0}^{T_{a}}[w(t)-\bar{w}] \times\left[c\left(t-\tau_{\mathrm{del}}\right)-\bar{c}\right]
$$



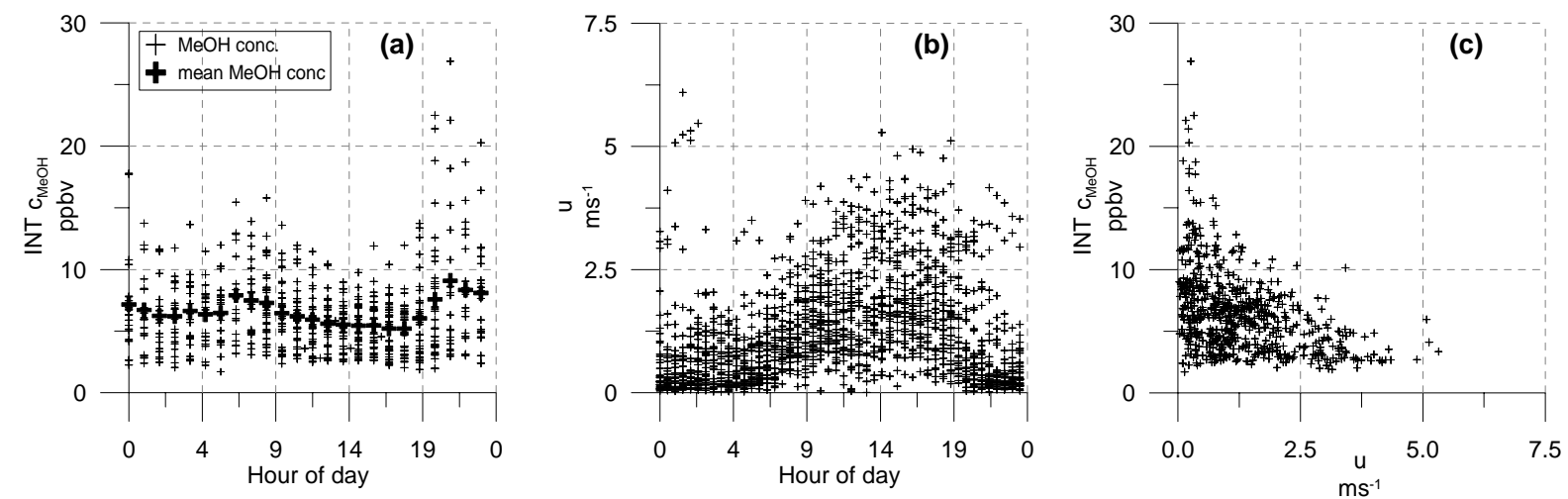

Fig. 4. Diurnal cycle of (a) methanol concentrations ( $\left.c_{\mathrm{MeOH}}\right)$ including hourly mean values above the intensive field, and (b) horizontal wind velocities $(u)$. (c) shows the scatter plot of methanol concentrations vs horizontal wind velocity. The data cover the period 25.06-01.08.2004.

The overbars denote the arithmetic mean of the averaging period. The two time series are adjusted to each other by a delay time $\tau_{\text {del }}$ that accounts for the residence time in the air sampling tube and possible time difference between the data acquisition systems that are different for the PTR-MS and the sonic anemometer. The time delay was calculated for each measuring interval separately by determining the maximum in the covariance function of the flux. In cases where no clear maximum could be found within the physically possible limits of the lag, an interpolated best guess for the lag was used (Ammann et al., 2006).

Beside the effect on the delay time, the inlet tube also led to a damping of high-frequent turbulent fluctuations of the trace gas concentrations before the detection by the PTRMS. As described in detail by Ammann et al. (2006), the wall sorption effect strongly dominated the high-frequency damping making other factors like the tube flow type, the limited time resolution, the filling of the disjunct time series, and the sensor separation distance less important. The total damping effect was quantified and corrected for by the empirical ogive method described in detail by Ammann et al. (2006). The high-frequency damping mainly depended on the wind speed and ranged between 25\% (low wind speed) and $55 \%$ (high wind speed). The detection limit of the EC fluxes was determined empirically from the standard deviation of the covariance function at large delay times according to Wienhold et al. (1995). It was estimated on average to $0.3 \mathrm{nmol} \mathrm{m}^{-2} \mathrm{~s}^{-1}$ and $0.8 \mathrm{nmol} \mathrm{m}^{-2} \mathrm{~s}^{-1}$ for the measurements above the intensive and extensive field, respectively. We performed a footprint analysis for the eddy covariance measurements (following Kormann and Meixner, 2001). Because of the low measurement height $(1.2 \mathrm{~m}$ above ground $)$ and the main wind directions being mostly along the field axis, there were only few cases $(c .5 \%)$ in which the footprint contribution of the study field was less than half. Most of the time, it was even more than $80 \%$. Therefore, the application of a footprint criteria was not considered to be necessary.

\section{Results}

\subsection{Measurements above the intensively managed field}

\subsubsection{Weather conditions and vegetation development}

During the summer 2004, average temperatures and precipitation at the measurement site were near the long-time seasonal mean. Above the intensive field methanol concentrations and fluxes were measured between 25 June and 1 August. As illustrated in Fig. 3, weather conditions during this time were characterised by two periods of contrasting weather. The first period (till 13 July) showed relatively low temperatures in connection with rain and clouds; it was followed by a mostly clear sky and dry period till the end of July.

The intensive field was cut on 25 June (2nd cut of the year). The hay was removed from the field on 26 June. The average dry matter yield of this growth was $0.32 \mathrm{~kg} \mathrm{~m}^{-2}$. After the fertilisation with slurry on 1 July, the grassland grew 8 weeks until the next cut on 28 August. On the same day the grass was processed to silage. The average dry matter yield of this growth was $0.19 \mathrm{~kg} \mathrm{~m}^{-2}$. The leaf area index increased from $0.3 \mathrm{~m}^{2} \mathrm{~m}^{-2}$ on 25 June (just after the cut) to $3.7 \mathrm{~m}^{2} \mathrm{~m}^{-2}$ on 19 August (last measurement before the $3 \mathrm{rd}$ cut) (see Fig. 2).

\subsubsection{Concentrations}

During the measurements on the intensive field, the concentrations were between 1.7 and 26.9 ppbv (Fig. 3), with an overall average concentration of 6.45 ppbv. Low concentrations were mainly detected during or after rainfall (e.g. 5-13 July). High concentrations were found shortly after the cut ( 28 June) and at the end of July. Figure 4a shows methanol concentrations plotted against the time of day. The mean concentration shows a characteristic diurnal variation. Highest concentrations were found in the late evening hours. 

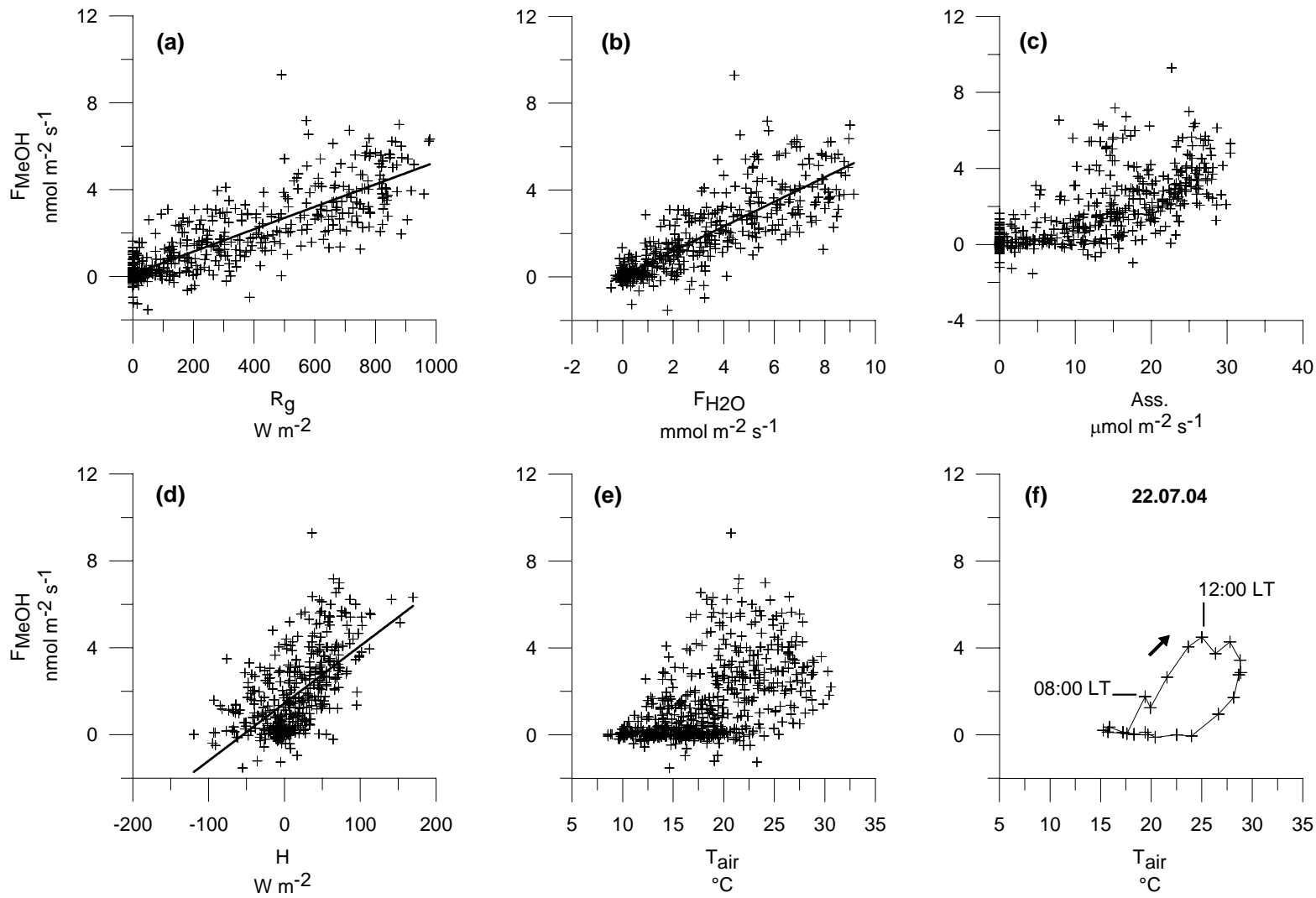

Fig. 5. Scatter plots of methanol flux $\left(F_{\mathrm{MeOH}}\right)$ vs (a) global radiation $\left(R_{g}\right)$, (b) water vapour flux $\left(F_{\mathrm{H}_{2} \mathrm{O}}\right)$, (c) assimilation (Ass.), (d) sensible heat flux $(H)$, and (e) air temperature $\left(T_{\text {air }}\right)$ above the intensive field for the period 28.06-01.08.2004. (f) shows the scatter plot of methanol flux and air temperature for one exemplary day (22.7.2004). The arrow indicates the direction of the diurnal course.

Table 1. Correlation coefficients $\left(r^{2}\right)$ of growth related methanol flux $\left(F_{\mathrm{MeOH}}\right)$ with various environmental parameters: global radiation $\left(R_{g}\right)$, water vapour flux $\left(F_{\mathrm{H}_{2} \mathrm{O}}\right)$, sensible heat flux $(H)$, carbon assimilation (Ass.), and air temperature $\left(T_{\text {air }}\right)$, calculated for the entire growing period and the mature period, respectively.

\begin{tabular}{lccccc}
\hline & $R_{g}$ & $F_{\mathrm{H}_{2} \mathrm{O}}$ & $H$ & Ass. $^{1}$ & $T_{\text {air }}^{1}$ \\
\hline INT (2.7.-1.8.) & 0.73 & 0.71 & 0.36 & 0.49 & 0.27 \\
INT mature (27.7.-1.8.) & 0.85 & 0.86 & 0.35 & 0.53 & 0.44 \\
EXT (16.6.-24.6., 2.8.-21.8.) & 0.70 & 0.64 & 0.53 & 0.54 & 0.21 \\
EXT mature (6.8.-11.8.) & 0.68 & 0.64 & 0.63 & 0.60 & 0.14 \\
\hline
\end{tabular}

1 non-linear dependence

They slowly decreased during the night and increased again around 07:00 LT. During daytime the concentrations dropped continuously to reach lowest levels around 18:00 LT. Figure 4 shows highest methanol concentrations to coincide with lowest wind speeds.

\subsubsection{Fluxes}

Methanol fluxes measured on the intensive grassland field are shown in Fig. 3. During the whole period methanol was emitted by the field, and no significant deposition fluxes could be observed. The highest fluxes (up to $30 \mathrm{nmol} \mathrm{m}^{-2} \mathrm{~s}^{-1}$ ) were measured directly after the cut on 25 June, which can be explained by amplified emissions due to plants wounding (De Gouw et al., 1999). Afterwards the fluxes were generally below $10 \mathrm{nmol} \mathrm{m}^{-2} \mathrm{~s}^{-1}$. They showed a clear diurnal cycle with the maximum around midday and the minimum during night. Nocturnal fluxes were generally small and mostly below the flux detection limit as quantified in Sect. 2.3. Since such fluxes would hardly pass a relative stationarity test as e.g. described by Foken and Wichura (1996), we did not apply such a quality filter. The diurnal cycle of methanol emission followed the global radiation and the water vapour flux in shape and strength. This is most obvious for the period 5-13 July that exhibit a very similar day-to-day variation of all quantities. The liquid manure treatment on 1 July let the emission of methanol rise temporarily with maximum emission of $12.4 \mathrm{nmol} \mathrm{m}^{-2} \mathrm{~s}^{-1}$. Measured methanol fluxes during night were mostly close to zero and/or below the detection limit of the EC method. 
Up to three days after a cut, methanol fluxes seem to be mostly triggered by the injury and the hay drying process. In order to investigate methanol emission during growth we excluded the data of the first three days after the cut. For the growing period 28.06-01.08.04, scatter plots of the methanol flux with various potential controlling parameters are shown in Fig. 5. They suggest a linear correlation between the methanol flux and the global radiation, the water vapour flux, and the sensible heat flux. These three correlations are positive. Further a logarithmic dependence can be seen between the methanol flux and the assimilation rate. Table 1 gives an overview of all calculated correlations coefficients $r^{2}$. Highest correlations exist between methanol flux and global radiation $\left(r^{2}=0.73\right)$, and water vapour flux $\left(r^{2}=0.71\right)$. The correlation of methanol flux and air temperature is low. It is likely to be a consequence of the diurnal cycle of the temperature which is similar but delayed in comparison to $R_{g}$ and $F_{\mathrm{H}_{2} \mathrm{O}}$. The resulting hysteresis becomes evident when looking at individual days as shown in Fig. $5 \mathrm{f}$.

In order to study the longer-term development of methanol emission, the strong short-term variability (diurnal and dayto-day) was sought to be reduced by dividing the observed methanol fluxes by the respective water vapour fluxes:

$\gamma(t)=\frac{F_{\mathrm{MeOH}}(t)}{F_{\mathrm{H}_{2} \mathrm{O}}(t)}$

As shown in Fig. 3, the water vapour flux shows diurnal and weather induced day-to-day variations but no systematic long-term trends. When plotting the ratio $\gamma(t)$ for the intensive grassland (Fig. 6), a systematic decrease with time was found. $\gamma$ almost linearly declined from an initial value of about $1.1 \mathrm{nmol} \mathrm{mmol}^{-1}$ one week after the cut down to $0.4 \mathrm{nmol} \mathrm{mmol}^{-1}$ within the first four weeks of growth. Afterwards (Fig. 6, Phase A), it stayed more or less constant. Thus normalised by the water vapour flux, methanol emission of the grassland ecosystem (per unit ground area) was three times higher shortly after the cut than four weeks later. If the methanol flux is related to the growing leaf area, the decrease in $\gamma / \mathrm{LAI}$ is even more pronounced with an almost exponential drop from an initial value of about 1.5 to only $0.2 \mathrm{nmol} \mathrm{mmol}^{-1}$ within the first four weeks, indicating that the young grassland vegetation emitted up to 7.5 times more methanol per leaf area than the mature one.

\subsection{Measurements above the extensively managed field}

\subsubsection{Weather conditions and vegetation development}

Above the extensive field, methanol concentrations were measured between 7 June and 7 September 2004 including the second growing period between the first and second cut. The measurements were not continuous due to an inserted measurement period above the intensive field (25 June-1 August). The weather conditions during the measurements above the extensive field were characterised by a relatively

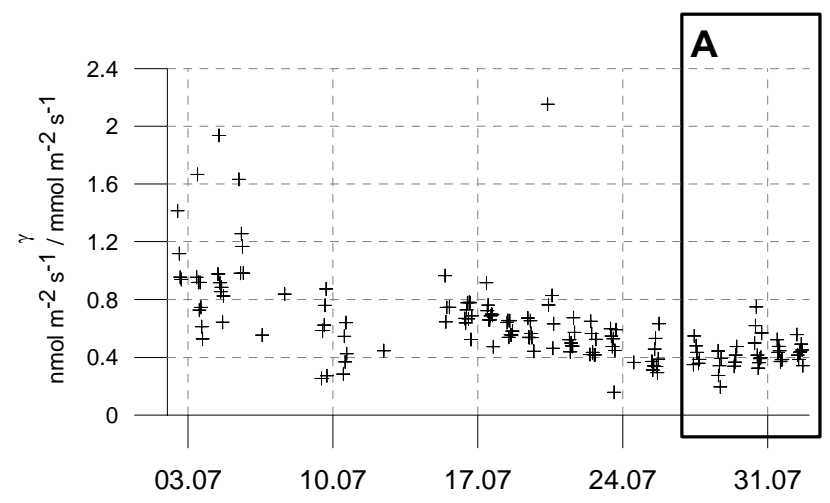

Fig. 6. Time series of $\gamma$ (for $F_{\mathrm{H}_{2} \mathrm{O}}>4 \mathrm{mmol} \mathrm{m}^{-2} \mathrm{~s}^{-1}$ ) of the intensive field for the period 02.07-01.08.2004. A: mature phase of the intensive field.

cold period in the middle of June and a relatively wet period starting in mid-August and lasting for two weeks (see Fig. 7).

The extensive field was cut on 7 June (1st cut of the year). The hay was removed from the field on 9 June. The dry matter yield of this growth was $0.67 \mathrm{~kg} \mathrm{~m}^{-2}$. Then the grassland grew 11 weeks until the next cut on 28 August (2nd cut of the year). On the same day the grass was processed to silage. The dry matter yield of this growth was $0.31 \mathrm{~kg} \mathrm{~m}^{-2}$. The leaf area index increased from about $0.2 \mathrm{~m}^{2} \mathrm{~m}^{-2}$ on 9 June (just after the 1 st cut) to $3.9 \mathrm{~m}^{2} \mathrm{~m}^{-2}$ on 19 August (last measurement before the 2nd cut) (see Fig. 2).

\subsubsection{Concentrations}

Methanol concentrations measured above the extensive field were between 0.38 and $47.8 \mathrm{ppbv}$, with an overall average of 7.38 ppbv (Fig. 7). Low concentrations were mainly during the relatively cold period in mid June and during the wet period in mid August. High concentrations were found shortly after the first cut ( 8 June). The mean diurnal cycle was very similar to that found above the intensive field (Fig. 4a) with one maximum in the evening (21:00 LT) and another in the morning (07:00 LT).

\subsubsection{Fluxes}

Figure 7 shows the methanol fluxes measured on the extensive field. Comparable to the intensive field, continuous methanol emission was detected during the whole growing period, and no significant deposition could by observed. The highest flux of $110.9 \mathrm{nmol} \mathrm{m}^{-2} \mathrm{~s}^{-1}$ was observed directly after the cut on 7 June. In general, the methanol emissions above the extensive field showed a similar diurnal cycle as the one seen above the intensive field. For the growing period (excluding the first three days after the cut) the methanol flux correlated best with global radiation and water vapour flux, as also found for the intensive field (see Table 1). The methanol emission normalised by the water 


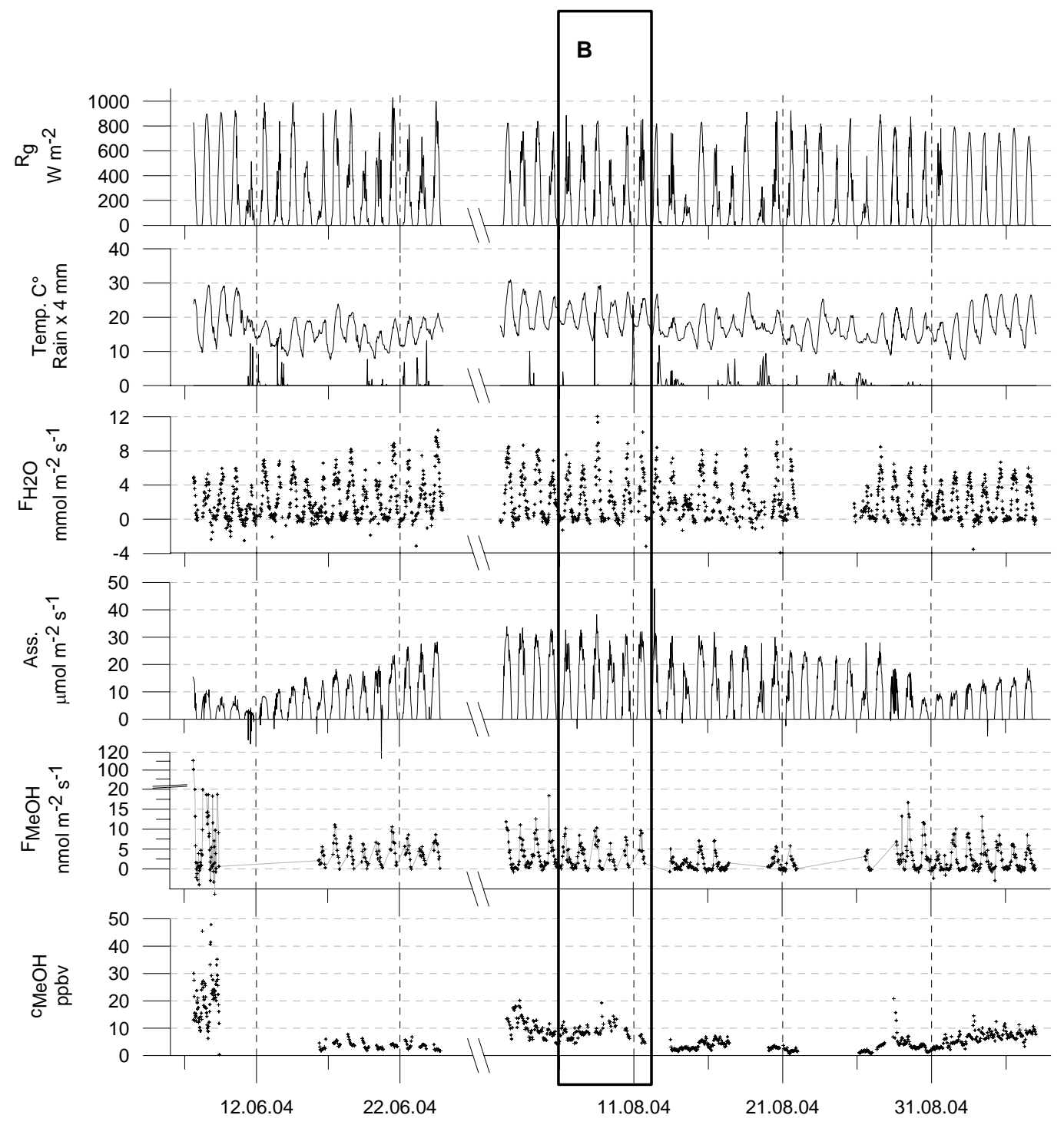

Fig. 7. Time series measured above the extensive grassland (07.06-07.09.2004), from the top to bottom: Global radiation* $\left(R_{g}\right)$, air temperature* (Temp.), rainfall*, water vapour flux $\left(F_{\mathrm{H}_{2} \mathrm{O}}\right)$, assimilation (Ass.), methanol flux $\left(F_{\mathrm{MeOH}}\right)$, and methanol concentration $\left(c_{\mathrm{MeOH}}\right)$. (B: mature phase of the extensive site). $*$ measured at the meteo station, see Fig. 1.

vapour flux ( $\gamma$ see Eq. 2) was very similar at the beginning and at the end of the growing phase with an average value of about $1 \mathrm{nmol} \mathrm{mmol}^{-1}$. However, the LAI related $\gamma(\gamma / \mathrm{LAI})$ showed a considerable decrease from 1 to $0.2 \mathrm{nmol} \mathrm{mmol}^{-1}$.

\subsection{Comparison of both fields}

The different plant composition of the two measurement fields could have an effect on the magnitude and the diurnal variation of the methanol emission. A direct comparison of the emission rates of the two fields under identical weather conditions and growing state is not possible because they were cut at different dates and the measurements were performed alternately. Therefore we compared two 6-day peri- ods towards the end of the respective growing phase (Fig. 2a and $b$ ), which are both characterised by a rather steady LAI and assimilation rate (Figs. 3 and 7). These 6-day periods are hereinafter also called "mature" periods. The accumulated daytime (10:00-16:00 LT) carbon assimilation for these phases were $39.6 \mathrm{mgC} \mathrm{m}^{-2}$ and $42.4 \mathrm{mgC} \mathrm{m}^{-2}$ for the intensive and the extensive field, respectively. The corresponding LAI was $3.4 \mathrm{~m}^{2} \mathrm{~m}^{-2}$ (INT) and $5.1 \mathrm{~m}^{2} \mathrm{~m}^{-2}$ (EXT). The mean temperature was similar during these two measurement phases, while the later (EXT) period was characterised by a slightly higher relative humidity and lower solar radiation (Fig. 8, Table 2).

Figure 8 shows the mean diurnal cycles of the methanol flux, the water vapour flux, the global radiation, 
Table 2. Characteristics for the intensive and the extensive field during mature phase: 6-day mean of sum $(\Sigma)$ of global radiation $\left(\Sigma R_{g}\right)$, air temperature ( $T_{\text {air }}: 24 \mathrm{~h}$ mean), rainfall ( $\Sigma$ Rain), relative humidity (RH: $24 \mathrm{~h}$ mean), leaf area index (LAI), accumulated daytime (10:0016:00) carbon assimilation ( $\Sigma$ Ass. $)$, and the accumulated methanol emissions $(\Sigma \mathrm{MeOH})$.

\begin{tabular}{cccccccc}
\hline & $\begin{array}{c}\Sigma R_{g} \\
\mathrm{~kW} \mathrm{~h} \mathrm{~m}^{-2}\end{array}$ & $\begin{array}{c}T_{\text {air }} \\
{ }^{\circ} \mathrm{C}\end{array}$ & $\begin{array}{c}\Sigma \text { Rain } \\
\mathrm{mm}\end{array}$ & $\begin{array}{c}\mathrm{RH} \\
\%\end{array}$ & $\begin{array}{c}\text { LAI } \\
\mathrm{m}^{2} \mathrm{~m}^{-2}\end{array}$ & $\begin{array}{c}\Sigma \text { Ass. } \\
\mathrm{mgC} \mathrm{m}^{-2}\end{array}$ & $\begin{array}{c}\Sigma \mathrm{MeOH} \\
\mathrm{mgC} \mathrm{m}^{-2}\end{array}$ \\
\hline INT & 5910 & 19.5 & 0 & 66.2 & 3.4 & 39.5 & 2.8 \\
EXT & 4140 & 20.6 & 30.5 & 82.6 & 5.1 & 42.4 & 6.3 \\
\hline
\end{tabular}
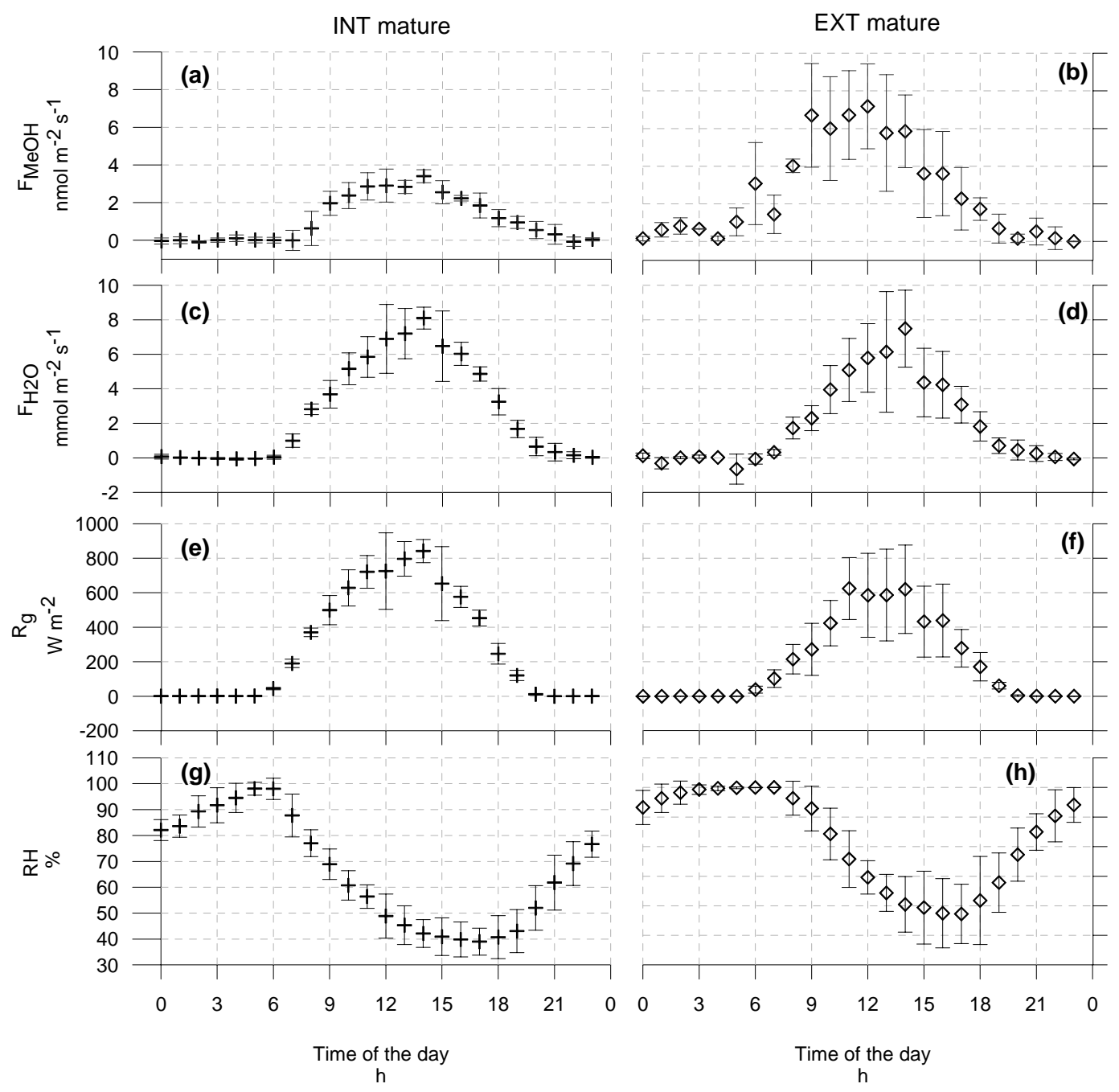

Fig. 8. Mean hourly values of the mature phase of the intensive (left, + ) and the extensive field (right, $\diamond):(\mathbf{a}, \mathbf{b})$ methanol flux $\left(F_{\mathrm{MeOH}}\right) ;(\mathbf{c}$, d) water vapour flux $\left(F_{\mathrm{H}_{2} \mathrm{O}}\right) ;(\mathbf{e}, \mathbf{f})$ global radiation $\left(R_{g}\right) ;(\mathbf{g}, \mathbf{h})$ relative humidity $(\mathrm{RH})$. Error bars are the standard deviation.

and the relative humidity for the two mature periods. The methanol flux reached a mean maximum emission flux of $3.40 \pm 0.34 \mathrm{nmol} \mathrm{m}^{-2} \mathrm{~s}^{-1}$ (14:00 LT) and $7.17 \pm 2.25 \mathrm{nmol} \mathrm{m}^{-2} \mathrm{~s}^{-1}$ (12:00 LT) above the intensive and the extensive field, respectively (Figs. 8a, b). The accumulated methanol emitted during these six days was $2.8 \mathrm{mgC} \mathrm{m}^{-2}$ and $6.3 \mathrm{mgC} \mathrm{m}^{-2}$ for the intensive and the ex- tensive field, respectively, i.e. a 2.3 times higher emission above the extensive field. If the emissions are normalised by the respective LAI, this ratio decreases to 1.5 . In contrast, the diurnal cycle of the mean hourly water vapour fluxes (Figs. 8c, d) reached quite similar maximum fluxes (INT: $8.1 \mathrm{mmol} \mathrm{m}^{-2} \mathrm{~s}^{-1}$, EXT: $7.5 \mathrm{mmol} \mathrm{m}^{-2} \mathrm{~s}^{-1}$ ). 

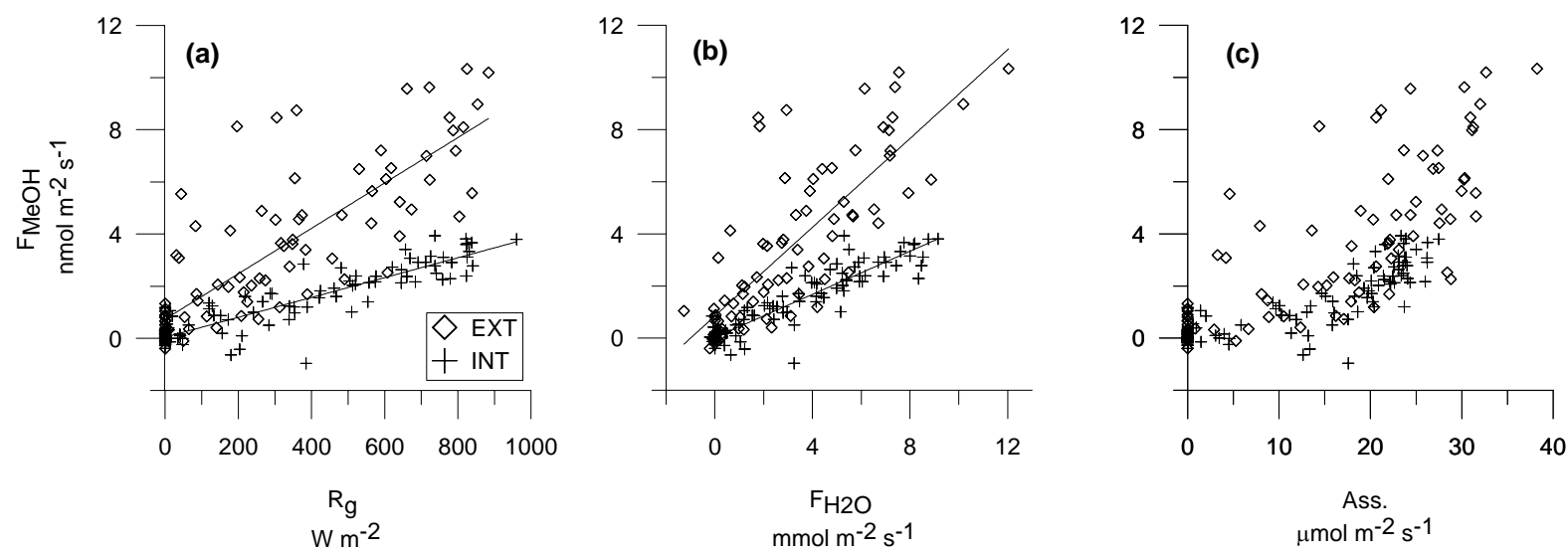

Fig. 9. Scatter plots of methanol flux $\left(F_{\mathrm{MeOH}}\right)$ vs (a) global radiation $\left(R_{g}\right)$, (b) water vapour $\left(F_{\mathrm{H}_{2} \mathrm{O}}\right)$, and (c) assimilation $($ Ass.) for the mature period of the intensive and the extensive fields (INT: + , EXT: $\diamond)$.

Figure 9 shows the scatter plots of the methanol flux with the global radiation, the water vapour, and the assimilation, respectively, for the intensive and the extensive field during the mature phase. They show positive linear correlations between the methanol flux and the global radiation as well as the water vapour flux. The dependence of the methanol flux and the assimilation seems to be non-linear. In accordance to the $\gamma$ values mentioned above, the intensive field shows a smaller slope between the methanol and the water vapour flux than the extensive field $\left(0.40 \mathrm{nmol} \mathrm{mmol}^{-1}\right.$ compared to $\left.0.92 \mathrm{nmol} \mathrm{mmol}^{-1}\right)$. The respective correlation coefficient of the intensive field $\left(r_{\text {INT }}^{2}=0.86\right)$ is significantly higher than the one of the extensive field $\left(r_{\mathrm{EXT}}^{2}=0.64\right)$. Part of the reduced correlation is due to a systematic difference in the diurnal cycles of methanol and water vapour fluxes; methanol emissions increase more rapidly before noon (Fig. 8). The same is true for the correlation between the methanol flux and the global radiation $\left(r_{\mathrm{INT}}^{2}=0.85, r_{\mathrm{EXT}}^{2}=0.64\right)$. The correlation coefficients between the methanol flux and the various environmental parameters for the mature phase are compiled in Table 1. In general, better correlations are found for the mature period alone than for the entire growing phase.

\section{Discussion}

\subsection{Concentrations}

The daily distribution of the methanol concentration above the intensive and the extensive grassland showed a diurnal cycle with two maxima (in the early evening and in the morning) and two minima (during night and in the afternoon). This cycle was observed during the growth and during the mature phase. The trend towards a minimum of methanol in the afternoon can be explained by the growth of the daytime convective boundary layer (CBL) leading to dilution and a relative depletion of methanol near the ground. With the break down of the thermal mixing after sunset a shallow stable nocturnal boundary layer (NBL) of about $50-100 \mathrm{~m}$ establishes. A methanol flux in the order of $0.1 \mathrm{nmol} \mathrm{m}^{-2} \mathrm{~s}^{-1}$ (i.e. smaller than our flux detection limit) into this NBL during these evening hours would be high enough to cause an increase of methanol concentrations up to $15 \mathrm{ppbv}$ as observed at the study site (Fig. 4a). The coincidence of the highest concentrations with low wind velocities (Fig. 4c) supports this interpretation, as the wind speeds at this site are generally very low in the NBL. Low methanol concentrations later during the night might be either due to a small loss process near the ground or a dilution by the growth of the NBL height. In the morning, the rising emissions into a yet shallow CBL may cause the increase in methanol concentration. The mean methanol concentrations of 5-10 ppb observed in this study fit in the range of typical rural background concentrations at the surface (e.g. Ammann et al., 2004; Das et al., 2003; Goldan et al., 1995; Warneke et al., 2002). Thus the methanol emissions from the agricultural fields together with reasonable assumptions about the diurnal course of the boundary layer height are sufficient to explain the major fluctuations of the observed methanol concentration. This indicates that advection of nearby anthropogenic sources is unlikely to play a dominant role during the experiment.

\subsection{Fluxes during growth}

Daytime methanol fluxes above the intensive and the extensive field were consistently positive indicating a general emission from the plants into the atmosphere (Figs. 3, 7 , 8, Table 3). The maximum fluxes not related to cut events were significantly higher above the extensive field ( $18.4 \mathrm{nmol} \mathrm{m}^{-2} \mathrm{~s}^{-1}$ corresponding to $2.21 \mathrm{mg} \mathrm{m}^{-2} \mathrm{~h}^{-1}$ ) than above the intensive field $\left(9.3 \mathrm{nmol} \mathrm{m}^{-2} \mathrm{~s}^{-1}\right.$ corresponding to $1.11 \mathrm{mg} \mathrm{m}^{-2} \mathrm{~h}^{-1}$ ). Compared to other measurements on grassland ecosystems, these values are slightly lower but of the same order of magnitude. Kirstine et al. (1998) 
Table 3. Methanol fluxes measured in field experiments.

\begin{tabular}{lllll}
\hline Reference & Plant species & Time of year & Flux measurement technique & $\begin{array}{l}\text { Fluxes (min-max) } \\
\mathrm{mg} \mathrm{m}^{-2} \mathrm{~h}^{-1}\end{array}$ \\
\hline $\begin{array}{l}\text { Fukui and Doskey (1998) } \\
\text { Kirstine et al. (1998) }\end{array}$ & Grassland & Summer & Static enclosure technique & $\sim 0.8^{1}$ \\
Kirstine et al. (1998) & White clover & Australian Summer & Static chamber & $0.36-0.49$ \\
Baker et al. (2001) & Subalpine forest & Summer 1999 & Static chamber & $0.03-7.5$ \\
Schade and Goldstein (2001) & Ponderosa pine & July-September 1999 & Relaxed Eddy Accumulation & $-0.1-2.5$ \\
Karl et al. (2002) & Subalpine forest & Summer 2001 & Virtual Disjunct Eddy & $0.25-1.09$ \\
& & & Covariance & $0.45-1.05$ \\
Warneke et al. (2002) & Alfalfa field & Summer 2000 & Disjunct Eddy Covariance & $0-4$ \\
Das et al. (2003) & Maize & May 1995 & Vertical gradient & $3.45^{2}$ \\
Karl et al. (2003) & Hardwood forest & Fall 2001-Summer 2002 & Disjunct Eddy Covariance & $0-2$ \\
Karl et al. (2004) & Rain forest & 2003 & Disjunct Eddy Covariance and & $0.13^{2}$ \\
& & & in-canopy gradient & Eddy Covariance, \\
Karl et al. (2005) & Loblolly pine forest & July 2003 & Relaxed Eddy Covariance and & $0.32-0.52^{2}$ \\
& & & in-canopy gradient & Eddy Covariance \\
Spirig et al. (2005) & Deciduous forest & Summer 2003 & Eddy Covariance & $0-0.31$ \\
This study & Intensive grassland & Summer 2004 & Eddy Covariance & $-0.18-1.11\left(0.21^{2}\right)$ \\
This study & Extensive grassland & Summer 2004 & & \\
\hline
\end{tabular}

1 normalized to $25^{\circ} \mathrm{C}$

2 Average fluxes $(24 \mathrm{~h})$

detected maximum fluxes of $7.5 \mathrm{mg} \mathrm{m}^{-2} \mathrm{~h}^{-1}$ above a clover field, and Warneke et al. (2002) reported maximum fluxes of $4 \mathrm{mg} \mathrm{m}^{-2} \mathrm{~h}^{-1}$ above an alfalfa field. Nocturnal methanol fluxes in the present study were mostly below the detection limit of $0.3 \mathrm{nmol} \mathrm{m}^{-2} \mathrm{~s}^{-1}$ (INT) and $0.8 \mathrm{nmol} \mathrm{m}^{-2} \mathrm{~s}^{-1}$ (EXT). Similarly, Kirstine et al. (1998) using static chambers did not detect any VOCs emissions during darkness.

Strong correlations of the methanol flux with the water vapour flux as well as with global radiation were found in the present study. In literature, few correlations between methanol fluxes and environmental parameters have been reported for grassland. Kirstine et al. (1998) showed a linear dependence between total VOC emissions from grass or clover and the photosynthetically active radiation (PAR) $\left(r_{\text {grass }}^{2}=0.62, r_{\text {clover }}^{2}=0.64\right)$. Furthermore, they observed a clear correlation for total VOC fluxes and air temperature $\left(r_{\text {grass }}^{2}=0.54, r_{\text {clover }}^{2}=0.44\right)$. The good correlation between methanol and water vapour flux, especially for shorter time periods like the mature phase (Table 1, Fig. 9b), indicates a very similar diurnal and day-to-day time variation of the two fluxes. The water vapour flux mainly represents the transpiration of the grassland ecosystem, which is limited by stomatal aperture (stomatal conductance). MacDonald and Fall (1993) found in laboratory measurements that changes in stomatal conductance were closely followed by changes in methanol flux. Niinemets and Reichstein (2003a, b) described the controlling effect of stomatal conductance on methanol emission by its high water solubility. Thus the con- straining effect of stomatal conductance (open during day, nearly closed during night), can explain the strong diurnal cycle of methanol emission observed on both fields in this study.

The magnitude of daytime emissions also depends on the rate of methanol production within the plant. As mentioned in the introduction, the production is associated with the growth of plants, and Galbally and Kirstine (2002) distinguished two classes of low and high methanol emitter species. In particular graminoids of the family poaceae, among them the main forage grass species, are low methanol emitters while most other plants belong to the high emitters (Galbally and Kirstine, 2002 and references therein). In this study, the intensive field was mainly composed of graminoids of the family poaceae (85\%), whereas the extensive field was composed of graminoids (35\%), legumes (60\%), and forbs $(5 \%)$. This difference in the species composition may explain the generally higher emissions by the extensive field.

The growth rate of plants is not constant but varies with time, and thus may lead to temporal changes in methanol emissions. On a long term, MacDonald and Fall (1993) and Nemecek-Marshall et al. (1995) observed decreasing methanol emissions with plant age in laboratory experiments, and Fukui and Doskey (1998) found similar results in the field. In the present study, we also found that the normalised methanol flux $(\gamma)$ of the intensive field decreased over the growing period (Fig. 6). In contrast, no significant change in the normalised flux was observed for the extensive field. We 


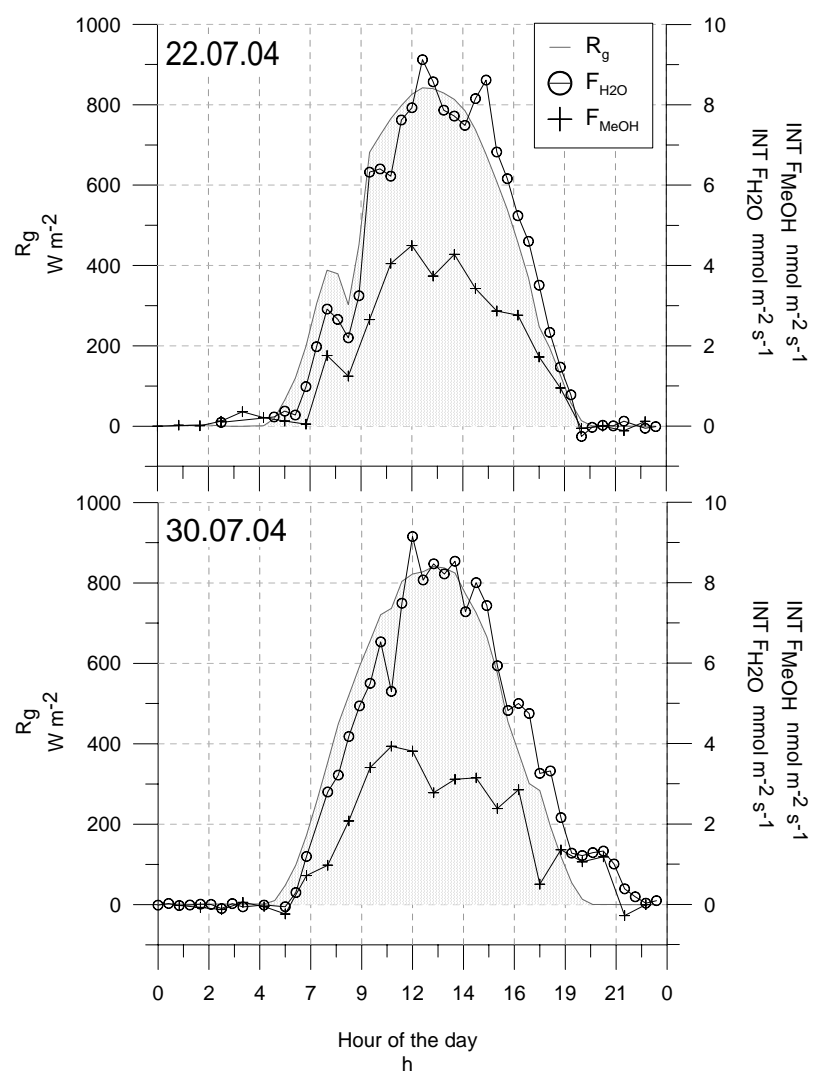

Fig. 10. Global radiation $\left(R_{g}\right)$, water vapour flux $\left(F_{\mathrm{H}_{2} \mathrm{O}}\right)$, methanol flux $\left(F_{\mathrm{MeOH}}\right)$ measured above the intensive field for the 22.07.04, and the 30.07.04.

attribute this effect to the high number of different species on the extensive field, which may have different individual growth dynamics.

On the short time scale, Körner and Woodward (1987) showed distinct diurnal cycles in growth with maximum rates at midday and minimum rates during night for five poa species (graminoids). Several other plant species, however, are known to grow mostly during night (Walter and Schurr, 2005). In these cases, the methanol produced in the leaf cannot be immediately released to the atmosphere because of the general closure of the stomata during night. Instead it may be temporarily accumulated in liquid pools (Niinemets and Reichstein, 2003a). With the opening of the stomata in the morning the pools are emptied leading to a transient emission peak (Nemecek-Marshall et al., 1995). Niinemets and Reichstein (2003b) simulated such peaks with a complex dynamic model including in-leaf pools for the accumulation of the nocturnally produced methanol. In our study, a short peak at sunrise (06:00 LT) was occasionally detected above the extensive field (Fig. 8b). However, the generally rapid increase of the methanol emission between 07:00 and 09:00 LT may also reflect a slower release of an accumulated pool.

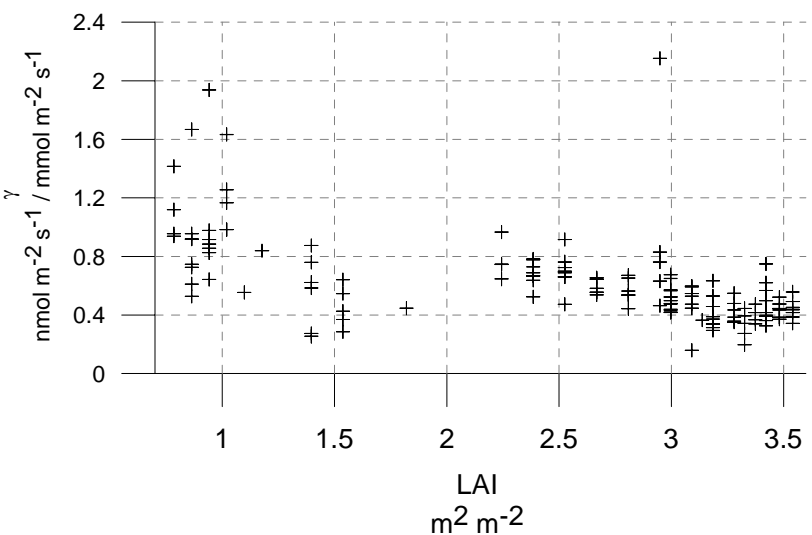

Fig. 11. $\gamma$ versus LAI of the intensive field for the period 02.0701.08.2004.

\subsection{Empirical flux parameterisation}

We looked for a simple empirical parameterisation which is able to describe the diurnal and day-to-day variation of the methanol emission as well as its long-term development during the growing phase. One aim of the parameterisation was to calculate missing data that are required for the estimation of the cumulated methanol emission of the entire growing season.

Since the correlation coefficients between $F_{\mathrm{MeOH}}$ and $R_{g}$ or $F_{\mathrm{H}_{2} \mathrm{O}}$, respectively, are both fairly high and not significantly different from each other, both $R_{g}$ and $F_{\mathrm{H}_{2} \mathrm{O}}$ are suitable for a parameterisation. The global radiation represents a very basic environmental input parameter, which controls important factors such as the temperature and the photosynthesis. The water vapour flux is strongly limited by the stomatal aperture and therefore more evidently linked to plant physiology. We decided to use the water vapour flux as governing parameter. It also allowed to take into account nocturnal emissions that have occasionally been observed during the field experiment. An example for such a case is presented in Fig. 10.

In order to combine the diurnal variation and the growth related decrease on the longer time scale, we chose a multiplicative approach. The flux ratio $\gamma(t)$ (Eq. 2) could be linearly related to the $\operatorname{LAI}(t)$ describing the plant growth (Fig. 11):

$\gamma(t)=\gamma_{0}-\alpha \times \operatorname{LAI}(t)$

$\gamma_{0}$ represents the back-extrapolated flux ratio at the beginning of the growing phase and $\alpha$ stands for the linear decrease with increasing LAI. A combination of Eqs. (2) and (3) yields the time dependent parameterisation for the methanol flux:

$F_{\mathrm{MeOH}}(t)=\left[\gamma_{0}-\alpha \times \mathrm{LAI}(t)\right] \times F_{\mathrm{H}_{2} \mathrm{O}}(t)$,

with $\gamma_{0}=0.962$ and $\alpha=0.15$ for the intensive field, $\gamma_{0}=1$ and $\alpha \cong 0$ for the extensive field, $\left[F_{\mathrm{MeOH}}(t)\right]=\mathrm{nmol} \mathrm{m}^{-2} \mathrm{~s}^{-1}$, and $\left[F_{\mathrm{H}_{2} \mathrm{O}}(t)\right]=\mathrm{mmol} \mathrm{m}^{-2} \mathrm{~s}^{-1}$. 


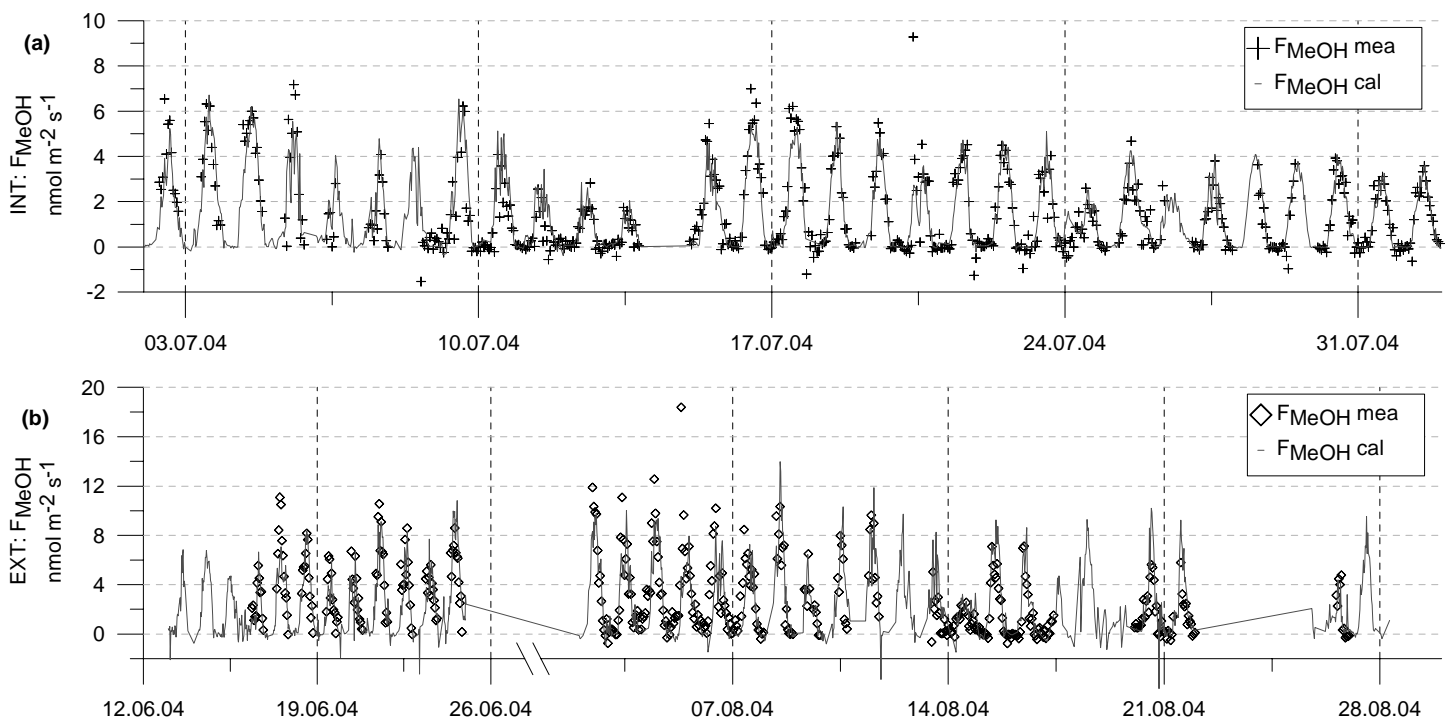

Fig. 12. (a) Methanol flux $\left(F_{\mathrm{MeOH}}\right)$ of the intensive field: measured (mea) and calculated (cal) by mean of the multiplicative approach. Correlation between measured and calculated methanol flux of the intensive field $\left(y=0.80 x+0.28 ; r^{2}=0.79\right)$. (b) Methanol flux $\left(F_{\mathrm{MeOH}}\right)$ of the extensive field: measured (mea) and calculated (cal) by mean of the multiplicative approach. Correlation between measured and calculated methanol flux of the extensive field $\left(y=0.79 x+0.79 ; r^{2}=0.64\right)$.

The parameters $\gamma_{0}$ and $\alpha$ were determined by a leastsquares fit to the measured data. As already described in 3.2.3, no growth related decrease of the flux ratio was observed on the extensive field $\left(\gamma_{0}=1\right)$, making the LAI term obsolete for this case. The two parameters differ for the two grassland fields most likely due to the different plant composition (see above).

Using this parameterisation we calculated continuous time series of methanol flux for both fields. Figure 12a shows the results for the intensive field together with the observed data. The overall correlation coefficient of calculated and measured methanol fluxes $\left(r^{2}=0.79\right)$ is higher than the correlation between methanol and water vapour flux (see Table 1), demonstrating the improvement by considering the growth effect. Figure $12 \mathrm{~b}$ shows the results for the extensive field together with the observed data.

\subsection{Time integrated methanol fluxes}

Until now, most investigations about VOC of grassland focused on short-term cut-related emissions (Fall et al., 1999 and 2001; de Gouw et al., 1999; Karl et al., 2001a, b, and 2005; Warneke et al., 2002). In this study we measured cutrelated as well as growth-related methanol emissions of two different grassland fields. We compare their integral contribution by referring them to the carbon content of the harvest yield $\left(\mathrm{C}_{\text {Harvest }}\right)$.

As mentioned in Sect. 2.1, the integral cut-related methanol emission was calculated from the methanol fluxes during the first three days after the cut (Fig. 2). This period is long enough to cover the cutting as well as the whole drying process for all cutting events. The growth-related methanol emission was taken as the accumulated methanol flux from the fourth day after the cut until the following cut. For this calculation, the time series of measured methanol fluxes was gap-filled using the parameterisation described in Sect. 4.3. The integrated methanol fluxes (expressed as carbon loss $\mathrm{C}_{\mathrm{MeOH}}$ ) and corresponding harvest yield are summarized in Table 4 . When normalized by the harvest yield, the growth related methanol emission of the extensive field was about two times higher than that of the intensive field. Thus the higher biomass on the extensive field could only explain a minor part of the emission difference (see also Sect. 3.3 and Fig. 8). The normalised methanol emissions of the cut and hay drying events were more than one order of magnitude lower than the respective growth-related emissions.

For comparison with literature values we referred the accumulated growth-related emissions to the respective net primary productivity (NPP). This information may also be useful for estimates of regional or national methanol emissions for comparison to other biogenic VOCs more commonly measured. Following Ryle (1984), NPP of the two growing periods was estimated as half of the cumulative carbon assimilation. The resulting normalised emissions $\mathrm{C}_{\mathrm{MeOH}} / \mathrm{NPP}$ were $0.024 \%$ for the intensive and $0.048 \%$ for the extensive field. Kirstine et al. (1998) found for an ungrazed grassland a total VOC emission of $0.25 \%$ of the annual NPP, with methanol accounting for $11-15 \%$. Thus their normalised methanol emission compares well with our results. The emission model of Galbally and Kirstine (2002) uses a methanol emission/NPP ratio for grasses of $0.024 \%$ and 
Table 4. Accumulated cut- and growth-related methanol emission $\left(\mathrm{C}_{\mathrm{MeOH}}\right)$, net primary productivity $(\mathrm{NPP})$, and harvest yield $\left(\mathrm{C}_{\mathrm{Harvest}}\right)$ of the intensive and the extensive grassland. Growth related emissions are referred to the harvest yield of the following cut.

\begin{tabular}{|c|c|c|c|c|c|c|c|}
\hline & Event/Phase & $\begin{array}{l}\text { Date } \\
\mathrm{gC} \mathrm{m}^{-2}\end{array}$ & $\begin{array}{l}\mathrm{C}_{\mathrm{MeOH}} \\
\mathrm{gC} \mathrm{m}^{-2}\end{array}$ & $\mathrm{C}_{\text {Harvest }}$ & $\begin{array}{c}\mathrm{C}_{\mathrm{MeOH}} / \mathrm{C}_{\text {Harvest }} \\
\mathrm{gC} \mathrm{m}^{-2}\end{array}$ & NPP & $\mathrm{C}_{\mathrm{MeOH}} / \mathrm{NPP}$ \\
\hline \multirow[t]{2}{*}{ INT } & Cut 2 & 25.6.-27.6.04 & 0.005 & 138 & $0.004 \%$ & & \\
\hline & Growth 3 & 28.6.-28.8.04 & 0.065 & 81 & $0.080 \%$ & 267 & $0.024 \%$ \\
\hline \multirow[t]{3}{*}{ EXT } & Cut 1 & 7.6.-9.6.04 & 0.028 & 288 & $0.010 \%$ & & \\
\hline & Growth 2 & 10.6.-28.8.04 & 0.199 & 133 & $0.150 \%$ & 415 & $0.048 \%$ \\
\hline & Cut 2 & 28.8.-30.8.04 & 0.007 & 133 & $0.005 \%$ & & \\
\hline
\end{tabular}

$0.11 \%$ for other higher plants. Considering that our intensive field was dominated by grasses whereas the extensive field consisted to more than half of non-graminoid species, the model is able to reasonably predict the emissions observed in this study.

\section{Conclusions}

Continuous flux measurements by an eddy covariance system over two managed grassland fields allowed the quantification of the methanol emissions on the ecosystem scale during the growing phase as well as during cut/hay drying events. The highest fluxes were measured directly after the cuts, which can be explained by amplified emissions due to plants wounding. However, both fields also showed continuous daytime methanol emissions during the growing periods between the cuts. The emission exhibited a distinct diurnal cycle with a maximum around midday. Measured methanol fluxes during night were mostly close to zero and/or below the detection limit of the eddy covariance method. On a dayto-day basis, the diurnal cycle strongly followed the global radiation and the water vapour flux. In the longer term, the emission of the intensive field significantly declined, whereas the one of the extensive field remained relatively constant over the whole growing phase. Accordingly, the observed variations of the methanol emission could be described by a simple empirical parameterisation using the water vapour flux and the leaf area index. The temporal course of the biogenic methanol emission in combination with the typical dynamics of the atmospheric boundary layer could explain at least qualitatively the variations of the local methanol concentration observed in this study.

On both fields, the accumulated carbon loss due to methanol emission was strongly dominated by the metabolism-related emission during the growing phase, which was more than ten times higher than the corresponding cut-related emission. The intensive field was dominated by graminoid species, which are known to be low methanol emitters due to their low pectin content in the cell walls (Galbally and Kirstine, 2002). The extensive field, on the other hand, consisted to more than $60 \%$ of non-graminoid species that are expected to have a higher pectin content and thus a higher methanol emission potential. This could explain the growing-phase emission found to be two times higher on the extensive than on the intensive field.

Acknowledgements. The work was financially supported by the Swiss National Science Foundation (Project COGAS, Nr. 200020101636).

Edited by: F. X. Meixner

\section{References}

Ammann, C., Spirig, C., Neftel, A., Komenda, M., Schaub, A., and Steinbacher, M.: Application of PTR-MS for biogenic VOC measurements in a deciduous forest, Int. J. Mass Spectrom., 239, 87-101, 2004.

Ammann, C., Brunner, A., Spirig, C., and Neftel, A.: Technical note: Water vapour concentration and flux measruements with PTR-MS, Atmos. Chem. Phys., 6, 4643-4651, 2006, http://www.atmos-chem-phys.net/6/4643/2006/.

Ammann, C., Flechard, C., Leifeld, J., Neftel, A., and Fuhrer, J.: The carbon budget of newly established temperate grassland depends on management intensity, Agriculture, Ecosyst. Environ., 121, doi:10.1016/j.agee.2006.12.002, 2007.

Das, M., Kang, D., Aneja, V. P., Lonneman, W., Cook, D. R., and Wesely, M. L.: Measurements of hydrocarbon air-surface exchange rates over maize, Atmos. Environ., 37, 2269-2277, 2003.

De Gouw, J. A., Howard, C. J., Custer, T. G., Baker, B. M., and Fall, R.: Emissions of volatile organic compounds from cut grass and clover are enhanced during the drying process, Geophys. Res. Lett., 26(7), 811-814, 1999.

Durand, J. L., Onillon, B., Schnyder, H., and Rademacher I.: Drought effects on cellular and spatial parameters of leaf growth in tall fescue, J. Exp. Bot., 46, 1147-1155, 1995.

Fall, R. and Monson, K.: Isoprene Emission Rate and Intercellular Isoprene Concentration as Influenced by Stomatal Distribution and Conductance, Plant Physiol., 100, 987-992, 1992.

Fall, R. and Benson, A. A.: Leaf methanol - the simplest natural product from plants, Trends Plant Sci., 1(9), 296-301, 1996.

Fehsenfeld, F., Calvert, J., Fall, R., Goldan, P., Guenther, A. B., Hewitt, C. N., Lamb, B., Liu, S., Trainer, M., Westberg, H., and Zimmerman, P.: Emissions of volatile organic compounds 
from vegetation and the implications for atmospheric chemistry, Global Biogeochem. Cy., 6(4), 389-430, 1992.

Flechard, C. R., Neftel, A., Jocher, M., Ammann, C., and Fuhrer, J.: Bi-directional soil/atmosphere $\mathrm{N}_{2} \mathrm{O}$ exchange over two mown grassland systems with contrasting management practices, Glob. Change Biol., 11, 2114-2127, 2005.

Foken, T. and Wichura, B.: Tools for quality assessment of surfacebased flux measurements, Agric. For. Meteorol., 78, 83-105, 1996.

Frenkel, C., Peters, J. S., Tieman, D. M., Tiznado, M. E., and Handa, A. K.: Pectin methylesterase regulates methanol and ethanol accumulation in ripening tomato (lycopersicon esculentum) fruit, J. Biol. Chem., 273(8), 4293-4295, 1998.

Fukui, Y. and Doskey, P. V.: Air-surface exchange of nonmethane organic compounds at a grassland site: Seasonal variations and stressed emissions, J. Geophys. Res., 103(D11), 13 153-13 168, 1998.

Galbally, I. E. and Kirstine, W.: The Production of Methanol by Flowering Plants and the Global Cycle of Methanol, J. Atmos. Chem., 43, 195-229, 2002.

Goldan, P. D., Kuster, W. C., Fehsenfeld, F., and Montzka, S. A.: Hydrocarbon measurements in the southeastern United States: The Rural Oxidants in the Southern Environment (ROSE) Program 1990, J. Geophys. Res., 100, 25 945-25 963, 1995.

Graedel, T. E. and Crutzen P. J.: Atmospheric change: An Earth System Perspective, W. H. Freeman, New York, 1993.

Guenther, A. B., Zimmermann, P. R., Harley, P. C., Monson, R. K., and Fall, R.: Isoprene and monoterpene emission rate variability: Model Evaluation and sensitivity analyses, J. Atmos. Chem., 45, 195-229, 1993.

Guenther, A.: Seasonal and spatial variations in natural volatile compound emission, Ecol. Appl., 7, 34-45, 1997.

Heikes, B. G., Chang, W., Pilson, M. E. Q., Swift, E., Singh, H. B., Guenther, A., Jacob, D. J., Field, B. D., Fall, R., Riemer, D., and Brand, L.: Atmospheric methanol budget and ocean implication, Global Biogeochem. Cy., 16(4), 1133, doi:10.1029/2002GB001894, 2002.

Holzinger, R., Warneke, C., Jordan, A., Hansel, A., and Lindinger, W.: Biomass Burning as a Source of Formaldehyde, Acetaldehyde, Methanol, Acetone, Acetonitrile and Hydrogen Cyanid, Geophys. Res. Lett., 26(8), 1161-1164, 1999.

Holzinger, R., Williams, J., Salisbury, G., Klüpfel, T., de Reus, M., Traub, T., Crutzen, P. J., and Lelieveld, J.: Oxygenated compounds in aged biomass burning plumes over the Eastern Mediterranean: evidence for strong secondary production of methanol and acetone, Atmos. Chem. Phys., 5, 39-46, 2005, http://www.atmos-chem-phys.net/5/39/2005/.

Isidorov, V. A., Zenkevich, I. G., and Ioffe, B. V.: Volatile organic compounds in the atmosphere of forests, Atmos. Environ., 19(1), $1-8,1985$.

Jacob, D. J., Field, B. D., Li, Q., Blake, D. R., de Gouw, J., Warneke, C., Hansel, A., Wisthaler, A., Singh, H. B., and Guenther, A.: Global budget of methanol: Constraints from atmospheric observations, J. Geophys. Res., 110, D08303, doi:10.1029/2004jd005172, 2005.

Karl, T., Guenther, A., Jordan, A., Fall, R., and Lindinger, W.: Eddy covariance measurement of biogenic oxygenated VOC emissions from hay harvesting, Atmos. Environ., 35, 491-495, 2001.

Karl, T., Spirig, C., Rinne, J., Stroud, C., Prevost, P., Greenberg, J.,
Fall, R., and Guenther, A.: Virtual disjunct eddy covariance measurements of organic compound fluxes from a subalpine forest using proton transfer reaction mass spectrometry, Atmos. Chem. Phys., 2, 1-13, 2002,

http://www.atmos-chem-phys.net/2/1/2002/.

Karl, T., Guenther, A., Spirig, C., Hansel, A., and Fall, R.: Seasonal variation of biogenic VOC emissions above a mixed hardwood forest in northern Michigan, Geophys. Res. Lett., 30(23), 2186, doi:10.1029/2003GL018432, 2003.

Karl, T., Harley, P., Guenther, A., Rasmussen, R., Baker, B., Jardine, K., and Nemitz, E.: The bi-directional exchange of oxygenated VOCs between a loblolly pine (Pinus taeda) plantation and the atmosphere, Atmos. Chem. Phys., 5, 3015-3031, 2005, http://www.atmos-chem-phys.net/5/3015/2005/.

Karl, T., Harren, F., Warneke, C., de Gouw, J., Grayless, C., and Fall, R.: Senescing grass crops as regional sources of reactive volatile organic compounds, J. Geophys. Res., 110, D15302, doi:10.1029/2005JD005777, 2005.

Kirstine, W., Galbally, I., Ye, Y., and Hooper, M.: Emissions of volatile organic compounds (primarily oxygenated species) from pasture, J. Geophys. Res., 103(D9), 10 605-10 619, 1998.

Kormann, R. and Meixner, F. X.: An analytical footprint model for non-neutral stratification, Bound.-Lay. Meteorol., 99, 207-224, 2001.

Körner, Ch. and Woodward, F. I.: The dynamics of leaf extension in plants with diverse altitudinal ranges, Oecologia (Berlin), 72, 279-283, 1987.

Lindinger, W., Hansel, A.., and Jordan, A.: On-line monitoring of volatile organic compounds at pptv levels by means of ProtonTransfer-Reaction Mass Spectrometry (PTR-MS) Medical applications, food control and environmental research, Int. J. Mass Spectrom., 173, 191-241, 1998.

Loreto, F., Barta, C., Brilli, F., and Nogues, I.: On the induction of volatile organic compounds emissions by plants as consequence of wounding or fluctuations of light and temperature, Plant Cell Environ., 29, 1820-1828, 2006.

MacDonald, R. C. and Fall, R.: Detection of substantial emission of methanol from plants to the atmosphere, Atmos. Environ., 27A(11), 1709-1713, 1993.

Monod, A., Chebbi, A., Durand-Jolibois, R., and Carlier, P.: Oxidation of methanol by hydroxyl radicals in aqueous solution under simulated cloud droplet conditions, Atmos. Environ., 34, 52835294, 2000.

Nemecek-Marshall, M., MacDonald, R. C., Franzen, J. J., Wojciechowski, C. L., and Fall, R.: Methanol Emission form Leaves, Plant Physiol., 108, 1359-1368, 1995.

Niinemets, Ü. and Reichstein, M.: Controls on the emission of plant volatiles through stomata: Differential sensitivity of emission rates to stomatal closure explained, J. Geophys. Res., 108(D7), 4208, doi:10.1029/2002JD002620, 2003a.

Niinemets, Ü. and Reichstein, M.: Controls on the emission of plant volatiles through stomata: A sensitivity analysis, J. Geophys. Res., 108(D7), 4211, doi:10.1029/2002JD002620, 2003 b.

Niinemets, Ü., Loreto, F., and Reichstein, M.: Physiological and physicochemical controls on foliar volatile organic compound emissions, Trends Plant Sci., 9(4), 180-186, 2004.

Obendorf, R. L., Koch, J. L., Gorecki, R. J., Amable, R. A., and Aveni, M. T.: Methanol Accumulation in Maturing Seeds, J. Exp. Bot., 41, 225, 489-495, 1990. 
Ryle, G. J. A.: Respiration and plant growth, in: Physiology and Biochemistry of Plant Respiration, edited by: Palmer J. M, Cambridge University Press, Cambridge, UK, 1984.

Schade, G. W. and Goldstein, A. H.: Fluxes of oxygenated volatile organic compounds from a ponderosa pine plantation, J. Geophys. Res., 106(D3), 3111-3123, 2001.

Schade, G. W. and Goldstein, A. H.: Seasonal measurements of acetone and methanol: Abundances and implications for atmospheric budgets, Global Biogeochem. Cy., 20, GB1011, doi:10.1029/2005GB002566, 2006.

Schulting, F. L., Meyer, G. M., and v. Aalst, R. M.: Emissie van koolwaterstoffen door vegetatie en de bijdrage aan de luchtverontreiniging in Nederland, Rapport CMP 80/16 AER 73, 1980.

Spirig, C., Neftel, A., Ammann, C., Dommen, J., Grabmer, W., Thielmann, A., Schaub, A., Beauchamp, J., Wisthaler, and A., Hansel, A.: Eddy covariance flux measurements of biogenic VOCs during ECHO 2003 using proton transfer reaction mass spectrometry, Atmos. Chem. Phys., 5, 465-481, 2005, http://www.atmos-chem-phys.net/5/465/2005/.
Tie, X., Guenther, A., and Holland, E.: Biogenic methanol and its impacts on tropospheric oxidants, Geophys. Res. Lett., 30(17), 1881, doi:10.1029/2003GL017167, 2003.

von Dahl, C., Hävecker, M., Schlogl, R., and Baldwin, I. T.: Caterpillar-elicited methanol emission: a new signal in plantherbivore interactions?, Plant J., 46, 948-960, 2006.

Walter, A. and Schurr, U.: Dynamics of Leaf and Root Growth: Endogenous Control versus Environmental Implact, Ann. Bot., 95, 891-900, 2005.

Warneke, C., Luxembourg, S. L., de Gouw, J. A., Rinne, H. J. I., Guenther, A. B., and Fall, R.: Disjunct eddy covariance measurements of oxygenated volatile organic compounds fluxes from an alfalfa field before and after cutting, J. Geophys. Res., 107(D8), 6-1-6-11, 2002.

Wienhold, F. G., Welling, M., and Harris, G. W.: Micrometeorological Measurement And Source Region Analysis Of NitrousOxide Fluxes From An Agricultural Soil, Atmos. Environ. 29(17), 2219-2227, 1995. 